\title{
Biodegradation of additive PHBV/PP-co-PE films buried in soil
}

\author{
Barbara Rani-Borges ${ }^{1}$, Adriano Uemura Faria ${ }^{1}$, Adriana de Campos², \\ Suely Patricia Costa Gonçalves ${ }^{1}$ and Sandra Mara Martins-Franchetti ${ }^{1 *}$
}

\author{
${ }^{1}$ Polymer Treatment Laboratory - LTP, Biochemistry and Microbiology Department, \\ Universidade Estadual Paulista - UNESP, Rio Claro, SP, Brazil \\ ${ }^{2}$ National Nanotechnology Laboratory for Agriculture - LNNA, Embrapa Instrumentação - EMBRAPA, \\ São Carlos, SP, Brazil \\ *sandrafranchetti@hotmail.com
}

\begin{abstract}
There is considerable concern about the impact plastic materials have on the environment due to their durability and resistance to degradation. The use of pro-oxidant additives in the polymer films could be a viable way to decrease the harmful effects of these discarded materials. In this study, films of PHBV/PP-co-PE (80/20 w/w) and PHBV/PP-co-PE/add $(80 / 19 / 1 \mathrm{w} / \mathrm{w} / \mathrm{w})$ (with pro-oxidant additive) were employed to verify the influence of the additive on the biodegradation of these films in the soil. These films were obtained by melting the pellets in a press at $180{ }^{\circ} \mathrm{C}$ which were buried in soil columns for 3 and 6 months. Some samples were also heated before being buried in soil. The biodegradation is higher for the additive blend buried for 3 months than for the pre-heated blend. After 6 months the blend buried and heated/buried was completely degraded in soil. The effect of the additive, on chain oxidation, is more time-dependant than heat-dependant.
\end{abstract}

Keywords: biodegradation, additive, blend, PHBV/PP-co-PE, soil.

\section{Introduction}

The increasing use of polymers by our society has resulted in a large quantities of discarded plastic materials in landfills $\mathrm{s}^{[1,2]}$. The polymers are employed as raw material to produce different products, such as soft drink bottles, supermarket bags, wall paints, toys, kitchenware, pipes, car dashboards, freezers, tables and many types of daily use items ${ }^{[3]}$. The inappropriate disposal of these materials is a cause for concern due to the following main characteristics: they are resistant to microbial degradation due to their hydrophobicity and high molecular weight ${ }^{[4-6]}$. To reduce the impacts of these recalcitrant materials in the environment, researchers are investigating some alternatives, as for example, the production of more degradable polymers, such as the biodegradable and oxo-biodegradable polymers which are less damaging to the environment and production blends composed of synthetic and biodegradable polymers ${ }^{[6,7]}$. Oxo-biodegradable polymers are synthetic polymers mixed with organic salts (stearate, carbamate) of metals such as cobalt, manganese, iron, etc ${ }^{[8]}$. These substances cause polymer chain scission in smaller fragments rich in oxygen groups, leading to a decrease in molecular weight and these chains used as carbon source by the microorganisms. According to $\operatorname{Scott}{ }^{[9]}$, the oxo-biodegradable polymers undergo a two-step degradation process: abiotic - chemical degradation accelerated by a catalyst, biotic-degradation using microorganisms, which assimilate the oxidation products.

The principle of oxo-biodegradable polymers is based on the addition of functional chemical groups to the polymer chain, which enables the material to disintegrate, facilitating the subsequent microbial biodegradation process $^{[10,11]}$.
Another alternative to minimize the damage caused by plastic disposal is implementing pre-treatment methods as UV radiation and heat to facilitate the microbial adhesion in the biodegradation process ${ }^{[12,13]}$.

The most widely used synthetic polymers are polyolefins: PP, PE, which when discarded in the environment have long term durability. These polymers can be mixed (blended) with a biodegradable polymer as poly(hydroxybutirate) (PHB) or poly(hydroxybutirate)-co-valerate (PHBV) and with pro-oxidant additives to make the material more degradable.

PP and PE are mechanically resistant, non biodegradable thermoplastic resins, widely used in different applications and produce large volumes of waste because of their resistance to microbial attack. These polymers are susceptible to UV light, oxidation and temperature ${ }^{[14]}$. Notwithstanding these limitations, they are economically viable cause produce a copolymer of PP and PE (PP-co-PE) ${ }^{[8,15]}$, a new material with more flexibility, processability and tenacity ${ }^{[16]}$.

The interest on polymer blends has grown recently due to the fact these materials match different properties originating new materials with good mechanical, chemical and thermal properties. Moreover, the cost to produce blends is less than the cost to produce new polymers ${ }^{[17-20]}$. In this work we used the blend PHBV/PP-co-PE (80:20 w/w), with a biodegradable and the synthetic copolymer, respectively.

Carashi et al. ${ }^{[19]}$ describe PHB as a natural polymer, produced by some types of bacteria in adequate culture media, and with good resistance to water steam and storage stability for shelf life of at least four years. It is a semi-crystalline 
polymer, very brittle, and this characteristic is improved when the PHBV copolymer is used ${ }^{[20]}$.

According to the American Society of Tests and Materials $(\mathrm{ASTM})^{[21]}$ and the International Organization of Normalization (ISO) $)^{[22]}$ degradation is an irreversible process that results in the structural modification of the polymer, which causes the loss of basic properties. This process is directly influenced by the environmental conditions, such as $\mathrm{pH}$, temperature, humidity, sun light and microbial composition ${ }^{[23]}$, besides the material structure, its surface area and morphology ${ }^{[24]}$. Biodegradation involves the microorganisms using the polymer as the sole carbon source, which then generate biofilm on the polymer surface, containing water and extracellular polymer substances that cause damage and scission of the macromolecular chain in simple molecules ${ }^{[25]}$. If the biodegradation is complete - mineralization - these simple molecules degrade in $\mathrm{CO}_{2}$, water and cellular biomass, in aerobic conditions or $\mathrm{CO}_{2}, \mathrm{CH}_{4}$ and biomass in anaerobic environment ${ }^{[26]}$. The breaking of polymeric bonds is related to the enzyme activity of the microorganisms in two ways: outside or inside of cells, i.e., exo or endo-biodegradation, respectively, or through a combination of these two ways ${ }^{[26]}$. The two processes are mediated by enzymes: the hydrolases and oxidases. The first process can break down the polymers by adding water molecules in the polymer chains, and the second one inserts oxygen (peroxide groups) in the chains which are also broken down ${ }^{[20,27]}$.

Biodegradation depends on the polymer composition, molecular weight, crystallinity, presence of functional groups, type of microorganisms ${ }^{[27-29]}$, therefore there are differences in the degradation stages that different polymers undergo: $\mathrm{PHBV}, \mathrm{PP} / \mathrm{PE}$ and polymers containing pro-oxidant additives:

> PHBV: this polymer contains hydrophilic groups able to interact with water molecules. The hydrolases convert the polymer into carboxyl acid, whereas the extracellular degradation produces 3-hydroxybutirate and 3-hydroxyvalerate molecules, which are metabolized inside cells, producing carbon dioxide and water ${ }^{[28]}$.

$>$ PP/PE: These polymers are considered inert due to their hydrophobic characteristics such as high molecular weight and lack of functional groups to facilitate the microbial attack ${ }^{[25]}$.

> Additive polymer: the oxi-biodegradable plastics undergo two degradation stages, abiotic and biotic. In the first stage there is a reduction in molecular weight by the oxidation chains, creating carboxylic acids, alcohols and ketones. This stage allows the second step: the chains become more hydrophilic favoring extracellular enzyme activity and subsequent breakdown of polymer chains $^{[30,31]}$.

Thus, the objective of this work is to investigate the biodegradation of poly(hydroxybutyrate-co-hidroxyvalerate) (PHBV) blended with polypropylene-co-polyethylene (PP-co-PE), with and without a pro-oxidant additive, through biotreatment in soil columns, using weight loss, scanning electronic microscopy (SEM), Fourier transform infrared (FTIR) and X-ray diffraction (XRD). There are different factors that affect biodegradability and to the best of our knowledge, there are a few papers that address biodegradation of PHBV blended with PP-co-PE, with and without a pro-oxidant additive. The effect of the additive depends on the biodegradation period and not on the heat pre-treatment.

\section{Materials and Methods}

\subsection{Materials}

PHBV with $6.2 \%$ of HV and Mø650.000 - was supplied by PHB Industrial SA, g/mol. PP-co-PE Mw 220.000 g/mol was supplied by Braskem. The pro-oxidant additive was supplied by RES Brazil LTDA, stated as manganese dithiocarbamate, impregnated in polyethylene matrix.

\subsection{Methods}

\subsubsection{Films preparation}

The blends PHBV/PP-co-PE (80/20w/w) and PHBV/PP-co-PE/add (80/19/1 w/w/w) with pro-oxidant additive were prepared using an internal mixer (Haake Torque Rheometer), $50 \mathrm{rpm}, 180{ }^{\circ} \mathrm{C}$ for 5 minutes. The blend composition chosen was to investigate how the synthetic copolymer (lower quantity) influences the material degradation. The materials were pressed at $170{ }^{\circ} \mathrm{C}$ under $71.3 \mathrm{kgfcm}^{-2}$ for $3 \mathrm{~min}$ to produce films of $5 \mathrm{~cm}$ diameter and $80-100 \mu \mathrm{m}$ thickness. The films (in duplicate) were sterilized before being placed in soil columns, with $2 \%$ solution of sodium hypochlorite.

\subsubsection{Treatments}

\subsubsection{Heat}

The films were heated in a vacuum oven (Marconi-MA030), at $100{ }^{\circ} \mathrm{C}$, for $40 \mathrm{~h}$. The heat treatment was applied for $5 \mathrm{~h} /$ day. The films were slowly cooled down inside the oven. Next, they were buried in soil columns.

\subsubsection{Buried-soil columns}

The soil columns were built using $1.5 \mathrm{~L}$ of PET bottles with small holes to aerate the soil during the experiment. The the bottle was partially filled with soil, $12 \mathrm{~cm}$ at the bottom of the bottle covered with the film, then more soil, $8 \mathrm{~cm}$, was placed over the film (Figure 1). The soil used was collected from the campus of Rio Claro, SP, Brazil, rich in humus, without litter and leaves, sieved with a $2 \mathrm{~mm}$ mesh, and initially adjusted to have $60 \%$ of humidity ${ }^{[32]}$. The humidity was maintained by a water recipient placed under the bottle, allowing the water to rise through capillarity, described by Campos et al. ${ }^{[33]}$ and shown in Figure 1. The columns were kept at room temperature for 3 months and 6 months (March and November /2012).

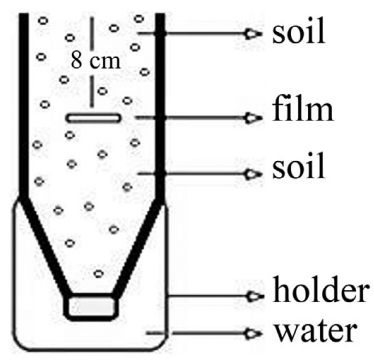

Figure 1. Soil column. 


\subsubsection{Characterization of the polymers}

\subsubsection{Weight loss}

The weight loss was evaluated by the difference in mass before and after the biotreatment, weighed on an analytical balance, CHYO, model JK200.

\subsubsection{Fourier Transform Infrared (FTIR)}

The original (before biological treatment) and biotreated films were analyzed by a Shimadzu IR Prestige 21 FTIR spectrometer, 16 scans with $4 \mathrm{~cm}^{-1}$ resolution, and range of 4000 to $400 \mathrm{~cm}^{-1}$. To compare the spectra before and after the soil treatment, each blend spectrum was normalized by the internal standard at $1460 \mathrm{~cm}^{-1}$, assigned to vibration of the $\mathrm{CH}_{2}$ groups, because this band does not change during the biodegradation process.

\subsubsection{X-Ray Diffraction (XRD)}

The samples were analyzed by XRD in a Shimadzu LABX-XRD 6000 diffractometer, operating at $30 \mathrm{kV}, 30 \mathrm{~mA}$ and $\mathrm{CuK} \alpha(\lambda 1.5406 \AA)$. The assays were performed at $25^{\circ} \mathrm{C}$, with $2 \Theta$ angles at 10 and $35^{\circ}\left(2^{\circ} / \mathrm{min}\right)$. Some samples were completely deteriorated after the biodegradation and were not measured.

The crystallinity degrees (Xc) were calculated by the ratio of the crystalline peak and the total area (crystalline + amorphous peaks), using the peak deconvolution method with Origin 7.5 software, using Gauss function to define the shape of the peaks, after the baseline correction.

\subsubsection{Scanning Electron Microscopy (SEM)}

SEM was used to investigate the surface morphology of the polymer in order to elucidate the material properties of polymers and behavior of some processes such as: thermal, photo-degradation and biodegradation ${ }^{[34]}$.

The polymer films before and after the heat and microbial treatments were analyzed by a scanning electron microscope - Zeiss DSM 940-A, using acceleration voltage of $5 \mathrm{kV}$ (ESALQ/USP - Piracicaba, SP).

\section{Results and Discussions}

After 3 and 6 months the PHBV/PP-co-PE films with and without additive were analyzed to verify morphological and structural changes, using the methods cited above.

Table 1. The weight loss of the samples.

\begin{tabular}{lcc}
\multicolumn{1}{c}{ Samples } & Buried & Heat/Buried \\
\hline PHBV & 90.1 & 100 \\
PP-co-PE & 0.12 & 0.23 \\
PHBV/ PP-co-PE & 77.0 & 93.0 \\
PHBV/PP-co-PE/Add & 88.0 & 94.0 \\
\hline
\end{tabular}

There was a significant weight loss in the blends, which was higher in the PHBV/PP-co-PE/Add blend (Table 1). The additive (pro-oxidant), favored the chains scission and biodegradation, but the presence of PHBV was also more significant to biodegradation.

After 6 months, the blends with additive were not found in the soil columns, just some small pieces of the blend without additive, thus the weight loss was considered to be $100 \%$.

FTIR measurements compare the spectra of the films before and after the heat and soil treatment (Figure 2). These spectra were normalized by an internal standard band (here called $\mathrm{A}_{0}$ ) at $1460 \mathrm{~cm}^{-1}$ (assigned to the PHBV CH deformation, as this band does not change after treatment) and deconvolution applied by the Lorentzian function to adjust the curves and isolate each band with the corresponding area, from the overlapping bands, increasing the spectrum resolution $^{[35]}$.

Table 2 shows a comparison of carbonyl indices in the amorphous and crystalline phases from the original and treated spectra, which were calculated by the areas ratio: $\mathrm{A}_{\mathrm{C}=\mathrm{O}} / \mathrm{A}_{0}$ bands. In the $\mathrm{PHBV} / \mathrm{PP}-\mathrm{co}-\mathrm{PE}$ blend there was a significant decrease in $\mathrm{C}=\mathrm{O}$ indices, in both phases: amorphous and crystalline (51\% and $57 \%$, respectively), emphasizing that the blend with additive underwent more degradation ( $83 \%$ and $92 \%$, respectively), when compared with the neat samples. In the heated and buried samples there was a synergistic effect in the amorphous phase and the decrease in the $\mathrm{C}=\mathrm{O}$ was $81 \%$. Considering the two subsequent treatments, heat/buried, the additive samples showed the heat effect on the chain structure, before the soil treatment. These results showed that the action of the oxidant additive in the soil biodegradation process was very efficient, more efficient than the heat/buried degradation, leading to a greater scission of polymer chains, especially in the crystalline phase. This fact suggests that the less ordered valerate chains of the PHBV located at the edge of the PHB crystal nucleus favors the microbial action, as in the model proposed by Yoshie ${ }^{[36]}$. Sadi et al..$^{[37]}$ observed that PHB samples exposed to UV radiation caused several changes in the material, such as scission and crosslinking reactions. An initial delay in the biodegradation was also observed, which was related to a thin superficial layer with higher crystallinity of the samples exposed to UV radiation. However, this did not completely inhibit PHB decomposition and as this layer was consumed there was an improvement in the biodegradation due to the fact that the degraded molecules located underneath this layer did not reorganize themselves into crystals.

The PHBV/ PP-co-PE blends buried for 6 months were measured using the FTIR technique (using very small pieces) and the graphics (in Figure 2) showed that the remaining parts

Table 2. Comparison carbonyl indices in the amorphous and crystalline phases from the original and treated spectra of blends with and without additive.

\begin{tabular}{llccc}
\hline & Samples & Neat & Buried & Heat/Buried \\
\hline \multirow{2}{*}{ PHBV/PP-co-PE } & Amorphous phase $\left(\mathrm{A}_{1727 / 1460}\right)$ & $\mathbf{0 . 7 5}$ & $\mathbf{0 . 3 7}$ & $\mathbf{0 . 1 4}$ \\
& Crystalline phase $\left(\mathrm{A}_{1716 / 1460}\right)$ & $\mathbf{0 . 8 3}$ & $\mathbf{0 . 3 6}$ & $\mathbf{0 . 3 5}$ \\
\hline \multirow{2}{*}{ PHBV/PP-co-PE/Add } & Amorphous phase $\left(\mathrm{A}_{1751 / 460}\right)$ & 0.66 & 0.11 & 0.10 \\
& Crystalline phase $\left(\mathrm{A}_{1715 / 1460}\right)$ & 0.86 & 0.07 & 0.35 \\
\hline
\end{tabular}


in the samples were principally constituted by the synthetic copolymer, thus the PHBV was almost completely consumed (Figure 2a, b). PHBV/ PP-co-PE and PHBV/ PP-co-PE/add (heat/buried) were not found in the soil. In this period the additive blend buried in the soil also disappeared. These samples were considered totally biodegraded.

Table 3 shows the crystallinity degrees (Xc) of the polymer films before and after the heat treatment and Figure $3 \mathrm{a}, \mathrm{b}$ displays the diffractograms. The heat treatment caused a crystallinity increase of the blend (4\%) and additive blend $(12 \%)$, causing the annealing. Comparing these two blends, the crystallinity increased more in the additive blend than in the blend without additive, due to the fact that more chains break and reorganize. PP-co-PE blend films after heat/microbial treatment were not measured by XRD because they were too deteriorated.

Figure 4 shows the micrographs of $\mathrm{PHBV} / \mathrm{PP}-\mathrm{co}-\mathrm{PE}$ and PHBV/ PP-co-PE/add. These figures clearly show biodegradation on the surface of the samples, without and with additive, such as microbial adhesion and surface delamination of PHBV. The morphological changes in the blends with additive seem to be greater than in those without additive, according to the visual aspect of these damaged samples.

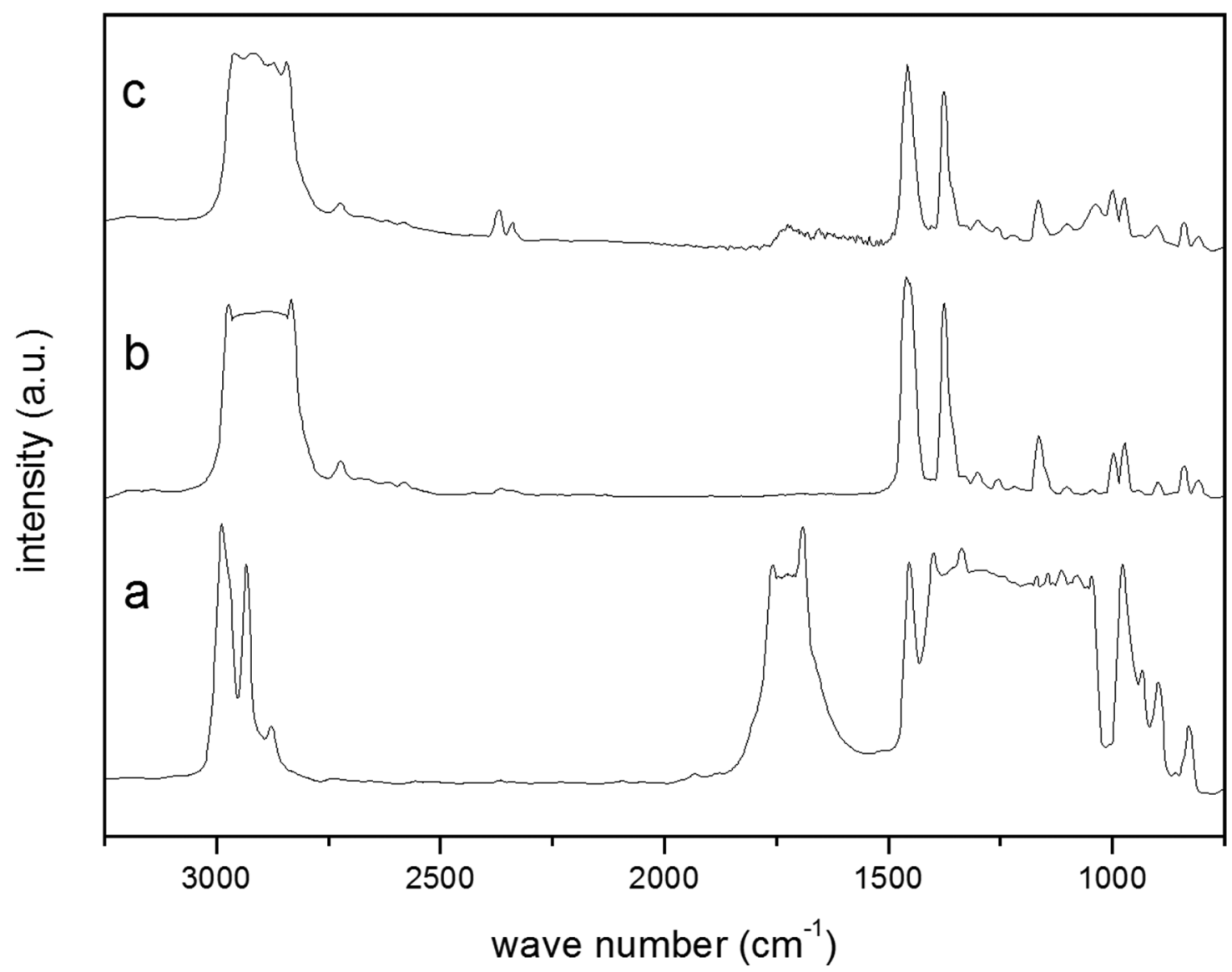

Figure 2. FTIR measurements comparison of the films before and after the heat and soil treatment.

Table 3. Crystallinity degrees (Xc) of the polymer films before and after the heat treatment.

\begin{tabular}{|c|c|c|c|c|}
\hline Samples & hkl & $2 \theta\left({ }^{\circ}\right)$ & D (nm) & $\% \mathrm{Xc}$ \\
\hline \multirow{2}{*}{ PHBV/PP-co-PE-neat } & $(020)_{\text {PHBV }}$ & 12.9 & 2.38 & \multirow{2}{*}{81} \\
\hline & $(110)_{\mathrm{PHBV}}(040)_{\mathrm{PP}}$ & 16.4 & 1.90 & \\
\hline \multirow{2}{*}{ PHBV/PP-co-PE-heat } & $(020)_{\text {PHBV }}$ & 13.7 & 2.52 & \multirow{2}{*}{85} \\
\hline & $(110)_{\mathrm{PHBV}}(040)_{\mathrm{PP}}$ & 17.0 & 1.91 & \\
\hline \multirow{2}{*}{ PHBV/PP-co-PE/Add - neat } & $(020)_{\text {PHBV }}$ & 12.9 & 2.37 & \multirow{2}{*}{69} \\
\hline & $(110)_{\mathrm{PHBV}}(040)_{\mathrm{PP}}$ & 16.4 & 1.90 & \\
\hline \multirow{2}{*}{ PHBV/PP-co-PE/Add -heat } & $(020)_{\text {PHBV }}$ & 12.9 & 2.86 & \multirow{2}{*}{81} \\
\hline & $(110)_{\mathrm{PHBV}}(040)_{\mathrm{PP}}$ & 16.4 & 2.19 & \\
\hline
\end{tabular}



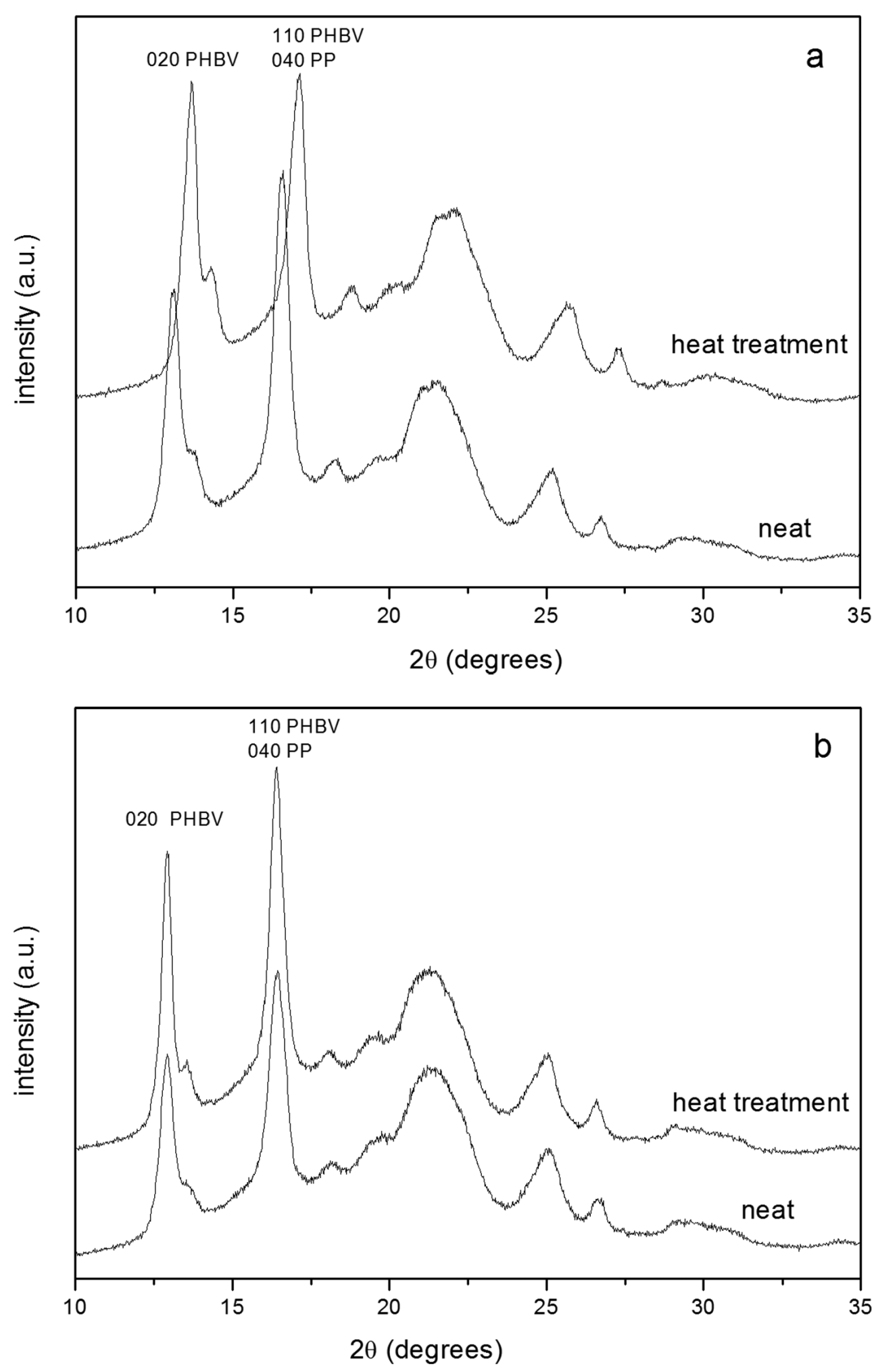

Figure 3. (a) Diffractograms of the PHBV/PP-co-PE films before and after the heat treatment; (b) Diffractograms of the PHBV/PP-co-PE/Add films before and after the heat treatment. 

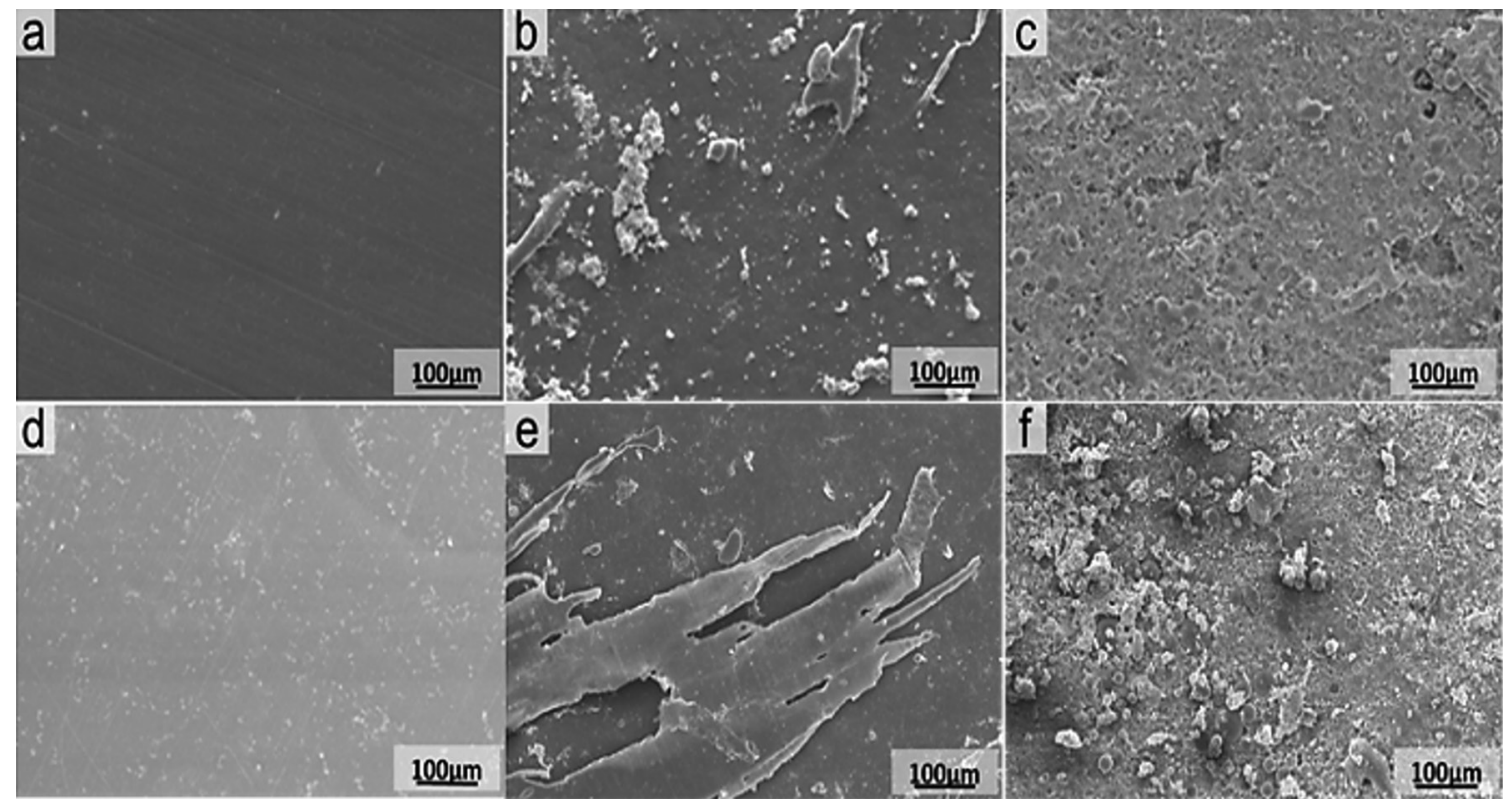

Figure 4. Micrograph of PHBV/ PP-co-PE (a, b, c) and PHBV/ PP-co-PE/add (d, e, f).

\section{Conclusions}

The PHBV/PP-co-PE blend heat/buried in soil for 3 months underwent significant degradation. In the buried additive blend the biodegradation was higher, i.e., the additive assisted the oxidation chains.

The PHBV/PP-co-PE blend heat/buried was completely degraded after 6 months. Moreover, the buried additive blend was mineralized in the soil. The action mechanism of the additive was not heat-dependant, showing that time was more influential.

\section{Acknowledgements}

The authors are grateful to Fapesp, CNPq and Capes for the grants, scholarship, and financial support.

The authors are also grateful to Dr. Marco Aurelio De Paoli from the Chemistry Institute, Unicamp, Campinas, SP, Brazil for his support in using the Haake Torque Rheometer and Dr. José A. M. Agnelli from Department of Materials Engineering, São Carlos Federal University, São Carlos, SP, Brazil for supplying the PHBV.

\section{References}

1. Coelho, N. S., Almeida, Y. M. B., \& Vinhas, G. M. (2008). A Biodegradabilidade da blenda de PHBV-Amido anfótero na presença de microrganismos. Polímeros: Ciência e Tecnologia, 18, 270-276. http://dx.doi.org/10.1590/S0104-14282008000300014.

2. Kumar, M., Mohanty, S., Nayak, S. K., \& Rahail, M. (2010). Effect of glycidylmethacrylate (GMA) on the thermal, mechanical and morphological property of biodegradable PLA/PBAT blend and its nanocomposites. Bioresource Technology, 101(21), 8406-8415. http://dx.doi.org/10.1016/j.biortech.2010.05.075. PMid:20573502.

3. Gonçalves, S. P. C., \& Martins-Franchetti, S. M. (2013). Respirometric evaluation of the biodegradability of films of
PE-PHBV blends. International Journal of Material Science, 3(2), 54-60.

4. Faria, A. U., \& Martins-Franchetti, S. M. (2010). Biodegradação de filmes de polipropileno (PP), Poli(3-hidroxibutirato) (PHB) e blenda de PP/PHB por microrganismos das águas do Rio Atibaia. Polímeros: Ciência e Tecnologia, 20(2), 141-147. http://dx.doi.org/10.1590/S0104-14282010005000024.

5. Rosa, D. S., Franco, B. L. M., \& Calil, M. G. (2001). Biodegradabilidade e propriedades mecânicas de novas misturas poliméricas. Polímeros: Ciência e Tecnologia, 11(2), 82-88. http://dx.doi.org/10.1590/S0104-14282001000200010.

6. Rosa, D. S., Chui, Q. S. H., Pantano Filho, R., \& Agnelli, J. A. M. (2002). Avaliação da Biodegradação de Poli- $\beta$ (Hidroxibutirato),Poli- $\beta$-(Hidroxibutirato-co-valerato) ePoli$\varepsilon$-(caprolactona) em solo compostado. Polímeros: Ciência e Tecnologia, 12(4), 311-317. http://dx.doi.org/10.1590/S010414282002000400015.

7. Silva, L. F., Gómez, J. G. C., Rocha, R. C. S., Taciro, M. K., \& Pradella, J. G. C. (2007). Produção biotecnológica de polihidroxialcanoatos para geração de polímeros biodegradáveis no Brasil. Quimica Nova, 30(7), 1732-1743. http://dx.doi. org/10.1590/S0100-40422007000700040.

8. Ojeda, T. F. M., Dalmolin, E., Forte, M., Jacques, R. J. S., Bento, F. M., \& Camargo, F. A. O. (2009). Abiotic and biotic degradation of oxo-biodegradable polyethylenes. Polymer Degradation \& Stability, 94(6), 965-970. http://dx.doi. org/10.1016/j.polymdegradstab.2009.03.011.

9. Scott, G. (2000). Greenpolymers. Polymer Degradation \& Stability, 68(1), 1-7. http://dx.doi.org/10.1016/S01413910(99)00182-2.

10. Chiellini, E., Corti, A., \& Swift, G. (2003). Biodegradation of thermally-oxidized, fragmented low-density polyethylenes. Polymer Degradation \& Stability, 81(2), 341-351. http://dx.doi. org/10.1016/S0141-3910(03)00105-8.

11. Fechine, G. J. M., Santos, J. A. B., \& Rabello, M. S. (2006). Avaliação da fotodegradação de poliolefinas através de exposição natural e artificial. Quimica Nova, 29(4), 674-680. http://dx.doi.org/10.1590/S0100-40422006000400009. 
12. Guedri, L., Amor, S. B., Gardettec, J. L., Jacqueta, M., \& Rivaton, A. (2005). Lifetime improvement of poly(ethylene naphthalate) by $\mathrm{ZnO}$ adhesive coatings. Polymer Degradation \& Stability, 88(2), 199-205. http://dx.doi.org/10.1016/j. polymdegradstab.2004.05.015.

13. Wilhelm, H. M., \& Felisberti, M. I. J. (2002). Reactive compatibilization of maleated polypropylene and maleatedpoly(styrene-b-butadiene-b-styrene) blends. Journal of Applied Polymer Science, 86(2), 366-371. http://dx.doi. org/10.1002/app.10977.

14. Coutinho, F. M. B., Mello, I. L., \& Santa Maria, L. C. (2003). Polietileno: Principais tipos, propriedades e aplicações. Polímeros: Ciência e Tecnologia, 13(1), 1-13. http://dx.doi. org/10.1590/S0104-14282003000100005.

15. Fernandes, L. L., Freitas, C. A., Demarquette, N. R., \& Fechine, G. J. M. (2012). Estudo do efeito do tipo de polipropileno na fotodegradação da blenda polipropileno/poliestireno de alto impacto. Polímeros: Ciência e Tecnologia, 22(1), 61-68. http:// dx.doi.org/10.1590/S0104-14282012005000013.

16. Silva, D. F., Araújo, E. M., \& Melo, T. J. A. (2012). Desenvolvimento de blendas de poliamida 6/composto de borracha reciclada (SBR-R). Revista Eletrônica de Materiais e Processos, 7(2), 104-110.

17. Chen, J. H., Zhong, J. C., Cai, Y. H., Su, W. B., \& Yang, Y. B. (2007). Morphology and thermal properties in the binary blends of polypropylene-co-ethylene copolymer and isotatic polypropylene with polyethylene. Polymer, 48(10), 2946-2957. http://dx.doi.org/10.1016/j.polymer.2007.03.037.

18. Pospíšil, J., Horák, Z., Kruliš, Z., Nešpůrek, S., \& Kuroda, S. (1999). Degradation and aging of polymers blends. Polymer Degradation \& Stability, 65, 405-414. http://dx.doi.org/10.1016/ S0141-3910(99)00029-4

19. Carashi, J. C., Ramos, U. M., \& Leão, A. L. (2002). Compósitos biodegradáveis de polihidroxibutirato (PHB) reforçado com farinha de madeira: propriedades e degradação. Acta Scientiarum, 24(6), 1609-1614. http://dx.doi.org/10.4025/actascitechnol. v24i0.2475.

20. Franchetti, S. M. M., \& Marconato, J. C. (2006). Polímeros biodegradáveis: uma solução parcial para diminuir a quantidade dos resíduos plásticos. Quimica Nova, 29(4), 811-816. http:// dx.doi.org/10.1590/S0100-40422006000400031.

21. American Society for Testing and Materials - ASTM. (1991). ASTM D883: standard terminology relating to plastics. West Conshohocken: ASTM.

22. International Organization for Standardization - ISO. (1997) ISO 846: plastics: determination of behavior under the action of fungi and bacteria: evaluation of the action of microorganisms. Geneva: ISO.

23. Imam, S. H., Gordon, S. H., Shogren, R. L., Tosteson, T. R., Govind, N. S., \& Greene, R. V. (1999). Degradation of starch PHBV bioplastic. Applied and Environmental Microbiology, 65, 431-437. PMid:9925564.

24. Chandra, R., \& Rustgi, R. (1998). Biodegradable polymers. Progress in Polymer Science, 23(7), 1273-1335. http://dx.doi. org/10.1016/S0079-6700(97)00039-7.

25. Arkatkar, A., Arutchelvi, J., Bhaduri, S., Uppara, P. V., \& Doble, M. (2009). Degradation of unpretreated and thermally pretreated polypropylene by soil consortia. International Biodeterioration \& Biodegradation, 63(1), 106-111. http:// dx.doi.org/10.1016/j.ibiod.2008.06.005.

26. Krzan, A., Hemjinda, S., Miertus, S., Corti, A., \& Chiellini, E. (2006). Standardization and certification in the area of environmentally degradable plastics. Polymer Degradation \& Stability, 91(12), 2819-2833. http://dx.doi.org/10.1016/j. polymdegradstab.2006.04.034.

27. Lucas, N., Christophe, B., Belloy, C., Queneudec, M., Silvestre, F., \& Nava-Saucedo, J. E. (2008). Polymer biodegradation: mechanisms and estimation techniques. Chemosphere, 73(4), 429-442. http://dx.doi.org/10.1016/j.chemosphere.2008.06.064. PMid: 18723204.

28. Shah, A. A., Hasan, F., Hameed, A., \& Ahmed, S. (2008). Biological degradation of plastics: a comprehensive review. Biotechnology Advances, 26(3), 246-265. http://dx.doi. org/10.1016/j.biotechadv.2007.12.005. PMid:18337047.

29. Priyanka, N., \& Aschana, T. (2011). Biodegradability of Polythene and plastics by the help of microorganism: A way for brighter future. Environmental and Analytical Toxicology, 1, 1-4. http://dx.doi.org/10.4172/2161-0525.1000111.

30. Brito, G. F., Agrawal, P., Araújo, M., \& Melo, T. J. A. (2011) Biopolímeros, polímeros biodegradáveis e polímeros verdes. Revista Eletrônica de Materiais e Processos, 6(2), 127-139.

31. De Paoli, M. A. (2008). Degradação e estabilização de polímeros. São Paulo: Editora Artliber.

32. Campos, A., Marconato, J. C., \& Martins-Franchetti, S. M. (2011). Biodegradation of blend films PVA/PVC, PVA/PCL in soil and soil with landfill leachate. Brazilian Archives of Biology and Technology, 54(6), 1367-1377. http://dx.doi. org/10.1590/S1516-89132011000600024.

33. Campos, A., Marconato, J. C., \& Martins-Franchetti, S. M (2010). Biodegradação de Filmes de PP/PCL em Solo e Solo com Chorume. Polímeros: Ciência e Tecnologia, 20(4), $295-$ 300. http://dx.doi.org/10.1590/S0104-14282010005000039.

34. Kaczmarek, H. (1996). Changes of polymer morphology caused by U.V. irradiation: surface damage polymer. Polymer Degradation \& Stability, 37, 189-194. http://dx.doi. org/10.1016/0032-3861(96)81086-X.

35. Araújo, S. C., \& Kawano, Y. (2001). Espectro Vibracional no infravermelho próximo dos polímeros poliestireno, poli(Metacrilato de Metila) e policarbonato. Polímeros: Ciência e Tecnologia, 11(4), 213-221. http://dx.doi.org/10.1590/S010414282001000400011

36. Yoshie, N., Saito, M., \& Inoue, Y. (2001). Structural Transition of lamella crystals in a isomorphous copolymer, poly(3hydroxybutyrate-co-3-hydroxyvalerate). Macromolecules, 34(26), 8953-8960. http://dx.doi.org/10.1021/ma0113071.

37. Sadi, R. K., Fechine, G. J. M., \& Demarquette, N. R. (2010). Photodegradation of poly(3-hydroxybutyrate). Polymer Degradation \& Stability, 95(12), 2318-2327. http://dx.doi. org/10.1016/j.polymdegradstab.2010.09.003.

Received: Mar. 11, 2015

Revised: Aug. 23, 2015

Accepted: Dec. 15, 2015 